\title{
PENGARUH KEPUASAN DAN KEPERCAYAAN TERHADAP LOYALITAS PELANGGAN JASA PENGIRIMAN BARANG JNE DI KOTA PALU
}

\author{
RIZAL ANUGRAH \\ JHONNY TANAMAL \\ ENKI P. NAINGGOLAN \\ Program Studi S1 Manajemen, Fakultas Ekonomi, Universitas Tadulako \\ Email: rizalanugrah004@gmail.com
}

\begin{abstract}
This study aims to determine customer satisfaction and trust both directly and partially to customer loyalty using JNE's freight forwarding service in Palu City. The independent variables in this study are satisfaction and trust. While the dependent variable is customer loyalty. The method used in this research is descriptive descriptive method. This type of research is descriptive causal. Empty sample of 75 respondents with purposive sampling sampling technique. Data analysis method used in this study is multiple linear regression using spss 21. The results of this study indicate that there is a significant relationship to customer loyalty by using JNE freight services in Palu City. partially satisfaction and significant loyalty to customer loyalty using JNE freight forwarding services in Palu City.

Keywords: Customer Satisfaction, Trust,Loyalty
\end{abstract}

\section{ABSTRAK}

Penelitian ini bertujuan untuk mengetahui pengaruh kepuasan dan kepercayaan pelanggan baik secara serempak maupun parsialterhadap loyalitas pelanggan menggunakan jasa pengiriman barang JNE Kota Palu.Variabel independen yang digunakan dalam penelitian ini adalah kepuasan dan kepercayaan.Sedangkan variabel dependen adalah loyalitas pelanggan.Metode yang digunakan dalam penelitian ini adalah metode deskriptif kuantitatif.Jenis penelitian yang dilakukan adalah deskriptif kausal. Sampel berjumlah 75 responden dengan teknik pengambilan sampel purposive sampling. Metodeanalisis data yang digunakan dalam penelitian ini adalah metode analisisregresilinear berganda dengan menggunakan spss 21 . Hasil penelitian ini menunjukkan bahwa secara simultan kepuasan dan kepercayaan berpengaruh signifikan terhadap loyalitas pelanggan menggunakan jasa pengiriman barang JNE di Kota Palu. secara parsial kepuasan dan kepercayaan berpengaruh signifikan terhadap loyalitas pelanggan menggunakan jasa pengiriman barang JNE di Kota Palu.

Kata Kunci: Kepuasan,Kepercayaan, Loyalitas Pelanggan

\section{PENDAHULUAN}

Kebutuhan seseorang semakin meningkat di iringi dengan banyaknya bisnis online yang bermunculan. Hal ini membuat seseorang dapat berbelanja, berjualan atau melakukan aktivitasnya sehari-hari secara online. Oleh karena itu aktivitas seseorang dapat dilakukan dengan sangat mudah dan praktis.Bisnis jasa pengiriman barang saat ini sangat di butuhkan dan berpengaruh dalam aktivitas konsumen sehari-hari.Hal ini mengakibatkan konsumen memiliki banyak pilihan untuk memilih tempat jasa pengiriman barang yang dapat di percaya, memberikan pelayanan terbaik, dan harga yang terjangkau, sehingga memudahkan kegiatan konsumen dalam hal pendistribusian barang dengan jarak jauh dapat tersalurkan dengan baik.

Saat ini bisnis online berkembang sangat pesat yang memicu tumbuhnya perusahaan ekspedisi (jasa pengiriman barang). Hal itu membuat persaingan dalam bisnis ekspedisi (jasa pengiriman barang) 
tampak ketat dan semakin terbuka lebar.Agar dapat bertahan dalam persaingan, perusahaan harus dapat membangun serta mempertahankan loyalitas pelanggannya. Loyalitas pelanggan memiliki peran penting dalam sebuah perusahaan. Mempertahankan mereka berarti meningkatkan kinerja keuangan dan mempertahankan kelangsungan hidup perusahaan.Manfaat dari loyalitas pelanggan adalah berkurangnya pengaruh serangan dari para kompetitor dari perusahaan sejenis.Selain itu pelanggan yang loyal dapat mendorong perkembangan perusahaan, karena mereka biasanya memberikan ide atau saran kepada perusahaan.

Untuk memperoleh loyalitas dari pelanggan, perusahaan harus mampu memuaskan pelanggannya.Setiap perusahaan dituntut untuk membuat pelanggan merasa puas dengan memberikan penawaran dan pelayanan yang baik, mengingat perusahaan harus mampu untuk mempertahankan posisi pasarnya ditengah persaingan yang semakin ketat.Untuk memenangkan persaingan, perusahaan harus mampu memberi kepuasan pada pelanggan. Upaya-upaya yang akan dilakukan oleh perusahaan untuk memuaskan kebutuhan konsumen dengan berbagai strategi dan berbagai cara dengan harapan agar pelanggan merasa puas dan selanjutnya mau untuk datang kembali. Apabila konsumen telah berubah menjadi konsumen yang loyal karena merasa puas kebutuhannya telah terpenuhi maka kemungkinan besar konsumen tidak akan pindah ke perusahaan lain. Artinya bila ada usaha dari perusahaan untuk meningkatkan kepuasan pada pelanggan maka loyalitas pelanggan juga akan meningkat begitu pula sebaliknya bila perusahaan menurunkan kepuasan pada pelanggan maka secara otomatis loyalitas pelanggan juga akan menurun. Jadi dalam hal ini kepuasan pelanggan merupakan penyebab terjadinya loyalitas pelanggan.

Selain kepuasan, kepercayaan juga merupakan salah satu faktor yang mempengaruhi loyalitas pelanggan.Menciptakan kepercayaan bagi konsumen adalah hal yang penting, mengingat salah satu alasan konsumen menjadi pelanggan yang loyal adalah berdasarkan kepercayaan konsumen terhadap suatu perusahaan.Pada dasarnya kepercayaan pelanggan adalah harapan yang dipegang konsumen bahwa suatu perusahaan dapat diandalkan dalam memenuhi kebutuhan konsumen.

Saat ini bisnis online berkembang sangat pesat yang memicu tumbuhnya perusahaan ekspedisi (jasa pengiriman barang). Hal itu membuat persaingan dalam bisnis ekspedisi (jasa pengiriman barang) tampak ketat dan semakin terbuka lebar. Agar dapat bertahan dalam persaingan, perusahaan harus dapat membangun serta mempertahankan loyalitas pelanggannya. Loyalitas pelanggan memiliki peran penting dalam sebuah perusahaan. Mempertahankan mereka berarti meningkatkan kinerja keuangan dan mempertahankan kelangsungan hidup perusahaan. Manfaat dari loyalitas pelanggan adalah berkurangnya pengaruh serangan dari para kompetitor dari perusahaan sejenis. Selain itu pelanggan yang loyal dapat mendorong perkembangan perusahaan, karena mereka biasanya memberikan ide atau saran kepada perusahaan.

Untuk memperoleh loyalitas dari pelanggan, perusahaan harus mampu memuaskan pelanggannya. Setiap perusahaan dituntut untuk membuat pelanggan merasa puas dengan memberikan penawaran dan pelayanan yang baik, mengingat perusahaan harus mampu untuk mempertahankan posisi pasarnya ditengah persaingan yang semakin ketat. Untuk memenangkan persaingan, perusahaan harus mampu memberi kepuasan pada pelanggan. Upaya-upaya yang akan dilakukan oleh perusahaan untuk memuaskan kebutuhan konsumen dengan berbagai strategi dan berbagai cara dengan harapan agar pelanggan merasa puas dan selanjutnya mau untuk datang kembali. Apabila konsumen telah berubah menjadi konsumen yang loyal karena merasa puas kebutuhannya telah terpenuhi maka kemungkinan besar konsumen tidak akan pindah ke perusahaan lain. Artinya bila ada usaha dari perusahaan untuk meningkatkan kepuasan pada pelanggan maka loyalitas pelanggan juga akan meningkat begitu pula 
sebaliknya bila perusahaan menurunkan kepuasan pada pelanggan maka secara otomatis loyalitas pelanggan juga akan menurun. Jadi dalam hal ini kepuasan pelanggan merupakan penyebab terjadinya loyalitas pelanggan.

Selain kepuasan, kepercayaan juga merupakan salah satu faktor yang mempengaruhi loyalitas pelanggan. Menciptakan kepercayaan bagi konsumen adalah hal yang penting, mengingat salah satu alasan konsumen menjadi pelanggan yang loyal adalah berdasarkan kepercayaan konsumen terhadap suatu perusahaan. Pada dasarnya kepercayaan pelanggan adalah harapan yang dipegang konsumen bahwa suatu perusahaan dapat diandalkan dalam memenuhi kebutuhan konsumen.

\section{KAJIAN LITERATUR DAN PENGEMBANGAN HIPOTESIS}

Menurut Kotler dan Keller (2013:143) jasa didefinisikan setiap tindakan atau perbuatan yang dapat ditawarkan oleh suatu pihak lain yang pada dasarnya bersifat intagible (tidak berwujud fisik) dan tidak menghasilkan kepemilikan sesuatu.

Menurut Tjiptono (2014:28) jasa memiliki sejumlah karakteristik unik yang membedakannya dari barang dan berdampak pada cara memasarkannya. Secara garis besar, karakteristik tersebut terdiri dari intagibility, inseparability, variability, dan perishability.

Intangibility ( tak berwujud)

Jasa berbeda dengan barang.Bila barang merupakan suatu objek, alat, atau benda, maka jasa adalah suatu perbuatan, tindakan, pengalaman, proses, kinerja, atau usaha.bahwa (tidak berwujud) Oleh sebab itu jasa tidak dapat dilihat, dirasa, dicium, didengar, atau diraba.

Inseparability (tak terpisah)

Barang biasanya diproduksi, kemudian dijual, dan dikonsumsi.sedangkan jasa pada umumnya dijual terlebih dahulu, baru kemudian diproduksi dan dikonsumsi pada waktu dan tempat yang sama. Jasa (tidak dapat dipisahkan) karena tidak dapat dipisahkan dari penyediannya, entah penyediannya itu manusia atau mesin.

Variability (bervariasi)

Jasa bersifat sangat variabel karena merupakan non-standardized output, artinya banyak variasi bentuk, kualitas, dan jenis, tergantung pada siapa, kapan, dan di mana jasa tersebut diproduksi.

Perishability (dapat musnah)

Bahwa jasa tidak tahan lama dan tidak dapat disimpan, bila permintaan bersifat konstan kondisi ini tidak menjadi masalah.Karena staf dan kapasitas penyedia jasa bisa dirancang untuk memenuhi permintaan.

Kepuasan pelanggan telah menjadi konsep sentral dalam teori dan praktek pemasar, serta merupakan salah satu tujuan penting bagi aktifitas bisnis. Kepuasan pelanggan berkontribusi pada sejumlah aspek seperti terciptanya loyalitas pelanggan dalam memenuhi kebutuhan. Definisi kepuasan pelanggan menurut Kotler dan Keller (2013:150) ialah: Perasaan senang atau kecewa yang muncul setelah membandingkan kinerja (hasil) produk yang dipikirkan terhadap kinerja (hasil) yang diharapkan.

Definisi di atas menunjukkan bahwa kepuasan pelanggan merupakan suatu pemenuhan harapan. Pelanggan dapat dikatakan puas dengan produk maupun pelayanan yang perusahaan berikan apabila harapan pelanggan akan produk/pelayanan yang perusahaan berikan tersebut telah sesuai bahkan melebihi harapan mereka. Pada industri jasa, kepuasan pelanggan diukur dengan tingkat kepuasan 
pelanggan berdasarkan keseluruhan pengalaman dengan perusahaan.Maka dari itu, kepuasan pelanggan perusahaan dapat diukur dengan tingkatannya berdasarkan keseluruhan pengalaman yang dirasakan para pelanggan selama berada di perusahaan tersebut. Lupiyoadi (2001:158) menyatakan bahwa dalam menentukan tingkat kepuasan, terdapat empat faktor utama yang harus diperhatikan oleh perusahaan, yaitu:

1. Kualitas Produk, Pelanggan akan merasa puas apabila hasil evaluasi mereka menunjukkan bahwa produk yang mereka gunakan berkualitas

2. Kualitas Pelayanan, terutama untuk industri jasa, pelanggan akan merasa puas bila mereka mendapatkan pelayanan yang baik atau yang sesuai dengan yang di harapkan

3. Emosional, Pelanggan akan merasa bangga dan mendapatkan keyakinan bahwa orang lain akan kagum terhadap dia bila menggunakan produk dengan merek tertentu yang cinderung mempunyai tingkat kepuasan lebih tinggi. Kepuasan yang di peroleh bukan karena kualitas dari produk tetapi nilai sosial atau self esteem yang membuat pelanggan menjadi puas terhadap merek tertentu.

4. Harga, Produk yang mempunya kualitas sama tetapi menetapkan harga yang relatif murah akan memberikan nilai yang lebih tinggi kepada pelanggannnya

Mowen dan Minor (2002:312) kepercayaan konsumen adalah semua pengetahuan yang dimiliki oleh konsumen dan semua kesimpulan yang dibuat konsumen tentang objek, atribut, dan manfaatnya. Objek dapat berupa produk, orang, perusahaan, dan segala sesuatu dimana seseorang memiliki kepercayaan dan sikap.

Kennedy (2002:75) kepercayaan pelanggan di ukur melalui empat indikator yaitu: Dependabiity, honest, competence, and likable. Dependability yaitu pelanggan menggantungkan harapan dan kepercayaannya pada janji di sampaikan perusahaan melalui pesan iklan dan personal selling kepada pelanggan.Semakin tinggi pelanggan menggantungkan harapannya kepada perusahaan untuk mendapat nilai yang di harapkan berarti pelanggan mempercayai perusahaan. Honesty Kejujuran yang melekat pada personil perusahaan. Kejujuran dalm kontek perusahaan adalah kejujuran yang melekat pada manusiannya dalam memberikan informasi dan layanan yang dibutuhkan pelanggan.Kejujuran personil (manusia) perusahaan dari sudut pandang pelanggan sangat penting karena pelanggan mempercayai perusahaan karena manusia yang bekerja di dalamnya jujur dan transparan dalam melayani dan memberikan informasi yang di butuhkan. Competenceyaitu "kompetensi perusahaan dan kompetensi sales person.Pembahasan awal adalah kompetensi perusahaan yang menjadi ke unggulan bersaing perusahaan di banding perusahaan pesaing.Misalnya profesionalisme staf, desain barang/jasa, citra rasa dari suatu produk, layanan unggul dan keunggulan teknologi. Likable yaitu sifat personil perusahaan dan sales person yang menyenangkan para pelanggan.Pelanggan menyenangi staf perusahaan karena sopanberbicara, ramah, berbusana rapih dan sifat suka membantu memecahkan masalah atau komplain pelanggan yang berkaitan dengan produk/jasa yang telah di beli.

Pada kondisi pasar dengan persaingan yang sangat tinggi, loyalitas menjadi elemen yang sangat penting bagi suatu perusahaan.Agar suatu perusahaan atau toko dapat bertahan dalam persaingan dan keluar sebagai pemenang, dibutuhkan konsumen dengan loyalitas yang tinggi.Loyalitas adalah tentang persentase dari konsumen yang pernah membeli di suatu perusahaan atau toko dalam jangka waktu tertentu kemudian melakukan pembelian kembali sejak pembeliannya pertama.

Griffin dalam Foster (2008:179) ada tujuh tahap pertumbuhan seseorang menjadi pelanggan yang loyal, yaitu:

1. Seseorang yang mempunyai kemungkinan pembeli (suspect)

Setiap orang mempunyai kemungkinan untuk membeli produk atau jasa yang dihasilkan.

2. Seseorang mempunyai potensi untuk menjadi pelanggan (prospect) 
Seseorang yang telah mempunyai kebutuhan akan barang dan mempunyai kebutuhan untuk membeli dari perusahaan dan telah ada seseorang yang merekomendasikan tentang perusahaan, membaca tentang perusahaan, prospect mungkin tahu siapa perusahaan, dan apa yang perusahaan jual tapi masih belum membeli dari perusahaan.

3. Seseorang yang mempunyai potensi yang tidak jadi menjadi pelanggan (disqualifed)

Prospect yang telah cukup perusahaan pelajari dan mereka tidak membutuhkan atau tidak mempunyai kemampuan untuk membeli atau menggunakan produk atau jasa perusahaan.

4. Pelanggan baru (first time customer)

Mereka yang baru pertama kali membeli dari perusahaan.Mereka mungkin pelanggan perusahaan tapi masih menjadi pelanggan pesaing perusahaan.

5. Pelanggan yang melakukan pembelian berulang (repeat customer)

Mereka yang pertama kali membeli dari perusahaan dua kali atau lebih, mereka mungkin telah membeli produk yang sama atau membeli dua produk yang berbeda dalam dua kali atau lebih kesempatan.

\section{Mitra (client)}

Seorang klien membeli semua yang perusahaan jual mungkin dapat ia gunakan. Orang ini membeli secara regular. Perusahaan harus terus berusaha menciptakan hubungan yang akan membuat dia tidak tertarik pada pesaing.

7. Pelanggan yang memajukan (advocate)

Seperti mitra, seorang advocate membeli semua yang perusahaan jual yang mungkin dapat dia gunakan dan membeli secara regular. Tambahannya seorang advocate akan berusaha menjadi orang lain untuk membeli dari perusahaan. Seorang advocate berbicara dengan perusahaan, melakukan pemasaran untuk perusahaan dan membawa pelanggan kepada perusahaan.

\section{Kerangka Pemikiran}

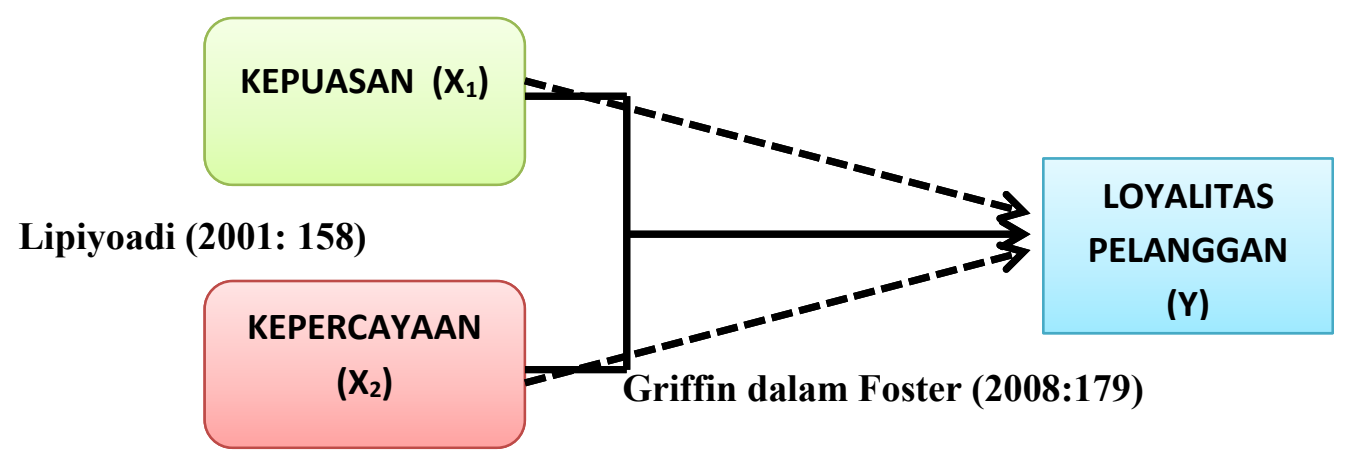

\section{Kennedy (2002:75)}

Keterangan: 


\section{Gambar 1}

\section{Kerangka Pemikiran}

\section{Hipotesis}

1. Kepuasan dan Kepercayaan pelangganberpengaruh signifikan secara Simultan terhadap loyalitas pelangganmenggunakan jasa JNE Kota Palu

2. Kepuasanberpengaruh signifikan secara parsial terhadap loyalitas pelanggan menggunakan jasa JNE Kota Palu

3. Kepercayaanberpengaruh signifikan secara parsial terhadap loyalitas Pelanggan mengunakan jasa JNE Kota Palu

\section{METODE PENELITIAN}

Jenis penelitian yang akan digunakan adalah deskriptif kausal. Metode deskriptif adalah metode yang digunakan untuk menggambarkan atau menganalisis suatu hasil penelitian tetapi tidak digunakan untuk membuat kesimpulan yang lebih luas, (Sugiyono, 2013: 42).Penelitian kausal adalah penelitian yang mempunyai tujuan utama yaitu membuktikan hubungan sebab dan akibat atau hubungan mempengaruhi dan dipengaruhi dari variabel yang diteliti.

Lokasi penelitian ini bertempat pada kantorJne Kota Palu J1.Moh hatta No 45 Palu Sulawesi Tengah. Alasan penelitian dilakukan di JNE Kota Palu karna peneliti melihat adanya fenomena yang terkait dengan variabel penelitiaan serta peneliti ingin mengetahui seberapa besarkah pengaruh Kepuasan dan Kepercayaan terhadap Loyalitas Pelanggan JNE Kota Palu.

Jumlah sampel pada penelitian ini merujuk pada Teori Roscoe dalam Sugiyono (2016:131) adalah minimal 10 kali dari jumlah variabel yang diteliti (variabel independen + variabel dependen).Jumlah variabel dalam penelitian ini adalah 3 yang terdiri dari variabel independen (kepuasan dan kepercayaan) dan variabel dependen (loyalitas pelanggan).Berdasarkan pertimbangan tersebut maka penulis menetapkan jumlah sampel yang digunakan dalam penelitian ini $25 \times 3$ variabel yaitu 75 responden.

1. Observasi

Observasi adalah teknik pengumpulan data dengan cara melakukan pengamatan langsung ke objek penelitian dan mempelajari segala sesuatu yang berkaitan dengan masalah yang akan diteliti disebuah organisasi agar mengetahui permasalahan sebenarnya.

2. Wawancara

Wawancara adalah teknik pengumpulan data dengan cara tanya jawab serta berhadapan langsung antara penanya dengan penjawab.

3. Kuesioner

Kuesioner adalah teknik pengumpulan data dengan cara membuat daftar pertanyaan yang berkaitan dengan penelitian dan kemudian disebarkan langsung kepada responden untuk mengisi kuesioner tersebut.

Agar data yang telah dikumpulkan dapat dimanfaatkan dengan baik, maka data tersebut harus diolah dan dianalisis terlebih dahulu sehingga dapat dijadikan dasar dalam pengembalian keputusan.Sebelum menggunakan metode analisis uji regresi linear berganda maka dilakukan terlebih dahulu uji asumsi klasik. 


\section{HASIL DAN PEMBAHASAN}

Tabel.1

Hasil Regresi Linear Berganda

\begin{tabular}{|l|c|c|c|c|c|}
\hline \multicolumn{7}{|c|}{ Dependen Variabel Y = Loyalitas Pelanggan } \\
\hline \multirow{2}{*}{ Variabel Independen } & $\begin{array}{c}\text { Unstandardized } \\
\text { Coefficients }\end{array}$ & $\begin{array}{c}\text { Standardized } \\
\text { Coefficients }\end{array}$ & T & Sig \\
\cline { 2 - 6 } & B & $\begin{array}{c}\text { Std. } \\
\text { Error }\end{array}$ & Beta & & \\
\hline C = Costanta &, 565 &, 301 & & 1,880 &, 064 \\
\hline Kepuasan $\left(\mathrm{X}_{1}\right)$ &, 662 &, 105 &, 640 & 6,286 &, 000 \\
\hline Kepercayaan $\left(\mathrm{X}_{2}\right)$ &, 218 &, 098 &, 227 & 2,234 &, 029 \\
\hline
\end{tabular}

Sumber: Lampiran Uji Asumsi Klasik, 2017

Berdasarkan tabel .1 di atas, dapat ditulis dalam bentuk persamaan regresi linear berganda.

Lebih jelasnya bentuk persamaan tersebut dapat dilihat sebagai berikut:

$\mathrm{Y}=\mathbf{0 , 5 6 5}+\mathbf{0 . 6 6 2} \mathrm{X1}+\mathbf{0 . 2 1 8} \mathrm{X2}$

Berdasarkan bentuk persamaan di atas, menunjukan bahwa variabel independen yang dianalisis yaitu variabel (X1 dan X2) memberi pengaruh positif terhadap variabel dependen (Y), yaitu loyalitas pelanggan menggunakan jasa JNE Kota Palu. Untuk lebih jelasnya penjelasan bentuk persamaan tersebut dapat dilihat berikut ini :

1. Nilai Konstanta sebesar 0,565, artinya jika variabel independen (Kepuasan dan Kepercayaan) bernilai 0 , maka variabel dependen (loyalitas pelanggan menggunakan JNE Kota Palu) nilainya sebesar 0,565.

2. Dilihat dari nilai Beta, variabel bebas $(\mathrm{X})$ yang berpengaruh dominan terhadap variabel terikat $(\mathrm{Y})$ adalah variabel Kepuasan (X1) karena variabel tersebut memiliki nilai Beta terbesar yaitu 0.640, sehingga dapat disimpulkan bahwa faktor Kepuasan Pelanggan pada JNE Kota Palu adalah variabel yang paling besar pengaruhnya terhadap loyalitas pelanggan.

3. Koefisien regresi variabel Kepuasan (X1) sebesar 0,662, artinya apabila Kepuasan meningkat 1 satuan, loyalitas pelanggan dalam menggunakan jasa JNE Kota Palu meningkat sebesar 0,662.

4. Koefisien regresi variabel Kepercayaan (X2) sebesar 0,218, artinya apabila Kepercayaan meningkat 1 satuan, loyalitas pelanggan dalam menggunakan jasa JNE Kota Palu meningkat sebesar 0,218.

\section{Uji F}

Tabel.2

\section{UJI SIMULTAN}

ANOVA $^{\mathrm{a}}$ 


\begin{tabular}{|rl|r|r|r|c|c|}
\hline \multicolumn{1}{|l|}{ Model } & \multicolumn{1}{c|}{$\begin{array}{c}\text { Sum of } \\
\text { Squares }\end{array}$} & Df & Mean Square & F & Sig. \\
\hline \multirow{2}{*}{1} & Regression & 10,772 & 2 & 5,386 & 77,047 &, $000^{\mathrm{b}}$ \\
& Residual & 5,033 & 72 &, 070 & & \\
& Total & 15,805 & 74 & & & \\
\hline
\end{tabular}

a. Dependent Variable: Y

b. Predictors: (Constant), X2, X1

\section{Sumber: Lampiran Uji Asumsi Klasik, 2017.}

Berdasarkan tabel .2 diperoleh nilai sig F yaitu 0.000, artinya nilai tersebut lebih kecil jika dibandingkan dengan nilai yang diisyaratkan yaitu $\alpha(0.05)$.jadi, dapat dinyatakan bahwa variabel kepuasan dan kepercayaanberpengaruh secara serempak dan signifikan terhadap loyalitas pelanggan menggunakan jasa JNE KotaPalu..

\section{Uji t}

Uji t dilakukan dengan membandingkan nilai t signifikansi lebih kecil dari $\square=0,05$ maka dapat dipastikan bahwa variabel independen berpengaruh signifikan terhadap variabel dependen, sebaliknya jika nilai t signifikansi lebih besar dari $\square=0,05$ maka dapat dipastikan bahwa variabel independen berpengaruh tidak signifikan terhadap variabel dependen, dapat dijelaskan hasil uji t dari variabel independen adalah sebagai berikut:

1. Kepuasan (X1)

variabel kepuasan memiliki nilai signifikansi 0,000 artinya nilai tersebut $<$ dari taraf signifikansi yang disyaratkan $\alpha=0.05$. jadi, maka dapat disimpulkan bahwa secara parsial kepuasan berpengaruh signifikan terhadap loyalitas pelanggan menggunakan jasa JNE Kota Palu dengan nilai koefisien regresi sebesar 0,662 . Dengan demikian hipotesis kedua terbukti

2. Kepercayaan (X2)

Variabel Kepercayaan memiliki nilai signifikansi 0.029 artinya nilai tersebut $<$ dari taraf signifikansi yang disyaratkan $\alpha=0.05$. jadi, dapat disimpulkan bahwa secara parsial Kepercayaanberpengaruh signifikan terhadap loyalitas pelanggan menggunakan jasa JNE KotaPalu dengan nilai koefisien regresi sebesar 0,218. Dengan demikian hipotesis ketiga terbukti.

\section{Pembahasan}

Kepuasan pelanggan telah menjadi konsep sentral dalam teori dan praktek pemasar, serta merupakan salah satu tujuan penting bagi aktifitas bisnis. Kepuasan pelanggan berkontribusi pada sejumlah aspek seperti terciptanya loyalitas pelanggan dalam memenuhi kebutuhan. Kepercayaan timbul dari suatu proses yang lama. Apabila kepercayaan sudah timbul antara pelanggan dan perusahaan, maka usaha untuk membina hubungan kerjasama akan lebih mudah. Kepercayaan dapat diperoleh karena melakukan sesuatu hal yang terbaik kepada pihak lain melalui suatu hubungan.

Berdasarkan uji $\mathrm{F}$ yang dilakukan, kepuasan dan Kepercayaan secara simultan berpengaruh signifikan terhadap loyalitas pelanggan. Hasil ini memberikan arti bahwa hipotesis pertama yang menyatakan kepuasan dan kepercayaan berpengaruh secara signifikan terhadap loyalitas pelanggan dapat diterima dan dapat diberi kesimpulan bahwa variabel independen dalam penelitian ini kepuasan 
dan kepercayaan merupakan faktor yang dapat mempengaruhi meningkatnya atau menurunnya loyalitas pelanggan.

Kepuasan pelanggan telah menjadi konsep sentral dalam teori dan praktek pemasar, serta merupakan salah satu tujuan penting bagi aktifitas bisnis. Kepuasan pelanggan berkontribusi pada sejumlah aspek seperti terciptanya loyalitas pelanggan dalam memenuhi kebutuhan. Berdasarkan penelitian yang di lakukan di JNE Kota Palu menunjukkan bahwa, JNE Kota Palu memberikan berbagai macam kepuasan untuk menciptakan loyalitas pelanggan dengan baik. Di lihat dari hasil penyebaran kuesioner terlihat bahwa pelanggan merasa puas sehingga tercipta loyalitas. Misalnya pada indikator daya tanggap pegawai JNE Kota Palu sangat memperhatikan daya tanggap pegawainya untuk memenuhi keinginan pelanggan.Hal tersebut membuat pelanggan merasa puas. Kemudian kenyamanan ruang tunggu konsumen, JNE Kota Palu sangat memperhatikan kenyamanan ruang tunggu konsumen dengan tujuan pelanggan merasakan suasana yang santai, maka akan menimbukan perasaan yang nyaman bagi pelanggan saat berada di ruang tunggu. Selanjutnya JNE Kota Palu juga menjamin lama pengiriman Barang sesuai dengan apa yang tercantum pada resi pengiriman agar pelanggan tidak merasa kecewa. Selain itu JNE Kota Palu juga memberikan harga yang terjangkau dengan tujuan untuk dapat menarik loyalitas pelanggan'

Berdasarkan hasil uji parsial, penelitian ini menunjukkan bahwa kepuasan secara parsial berpengaruh signifikan terhadap loyalitas pelanggan JNE Kota Palu. Artinya hipotesis ke dua pada penelitian ini di terima.Selanjutnya, berdasarkan hasil uji regresi linier berganda menunjukkan bahwa kepuasan berpengaruh positif terhadap loyalitas pelanggan. Artinya apabila JNE Kota Palu memberikan kepuasan dengan lebih baik lagi maka akan meningkatkan loyalitas pelanggan JNE Kota Palu.

Hasil penelitian ini mendukung yang dilakukan oleh Eni Hairani dan Marijati sagen (2014) dengan judul "Pengaruh kepuasan dan kepercayaan terhadap loyalitas pelanggan LPSB" martapura banjar.Hasil penelitan tersebut menunjukkan bahwa secara parsial kepuasan berpengaruh terhadap loyalitas pelanggan.

Kepercayaan merupakan hal yang harus ada dalam menjalin hubungan dengan pelanggan, jika suatu perusahaan ingin berhasil menjalin hubungan dengan pelanggan, perusahaan tersebut harus memperhatikan faktor-faktor kunci suskses dari usaha membina hubungan dengan pelanggan yaitu kepercayaan. adanya kepercayaan maka perusahaan mampu menciptakan pelanggan yang loyal karena telah mempercayai kinerja atau kemampuan produk dan perusahaan.

Berdasarkan penelitian yang di lakukan di JNE Kota Palu menunjukkan bahwa, JNE Kota Palu memeberikan berbagai macam kepercayaan untuk menciptakan loyalitas pelanggan dengan baik. Dilihat dari hasil penyebaran kuesioner terlihat bahwa pelanggan merasa puas sehingga tercipta loyalitas. Misalnya pada indikator JNE Kota Palu dapat memenuhi harapan terlihat pelanggan merasa percaya terhadap layanan yang di berikan JNE Kota Palu. Kemudian kepercayaan terhadap jaminan, JNE Kota Palu sangat memperhatikan jaminan keamana barang apabila kerusakan pada barang atau paket, pihak JNE Kota Palu siap bertanggung jawab penuh. Selanjutnya percaya bahwa barang yang dikirim akan sampai pada tempat tujuan, dalam pengantaran barang pihak JNE Kota Palu akan mengantarkan barang atau paket sesuai dengan alamat yang tertera pada resi pengiriman sehingga tidak ada keraguan dari pelanggan bahwa barang yang dikirim sampai ke alamat yang salah. Selanjutnya pegawai yang ramah saat melayani, pihak JNE Kota Palu sangat memperhatikan keramahannya pada saat melayani misalnya dalam berinteraksi pihak JNE Kota Palu berkomunikasi dengan baik dan sopan terhadap pelanggan sehingga pelanggan merasa nyaman pada saat berinteraksi 
dengan pihak JNE Kota Palu, hal ini akan menciptakan hubungan baik antara pihak JNE Kota Palu dan pelanggannya. selain itu keramahan kurir, pihak JNE Kota Palu sangat memperhatikan keramahan kurirnya. Sehingga pelanggan merasa nyaman dan bangga menjadi konsumen JNE Kota Palu.

Berdasarkan hasil uji parsial, penelitian ini menunjukkan bahwa kepercayaan secara parsial berpengaruh signifikan terhadap loyalitas pelanggan JNE Kota Palu. Artinya hipotesis ketiga pada penelitian ini di terima. Selanjutnya, berdasarkan hasil uji regresi linier berganda menunjukkan bahwa kepercayaan berpengaruh positif terhadap loyalitas pelanggan. Artinya apabila JNE Kota Palu memberikan kepercayaan dengan lebih baik lagi maka akan meningkatkan loyalitas pelanggan JNE Kota Palu. Hasil penelitian ini mendukung penelitian yang di lakukan oleh Wulandari, Kusuma Negara dan Kusuma Dewi (2016) dengan judul "Pengaruh kepuasan, kepercayaan dan harga terhadap loyalitas wisatawan pengguna Booking.com". hasil penelitian tersebut menunjukkan bahwa kepercayaan berpengaruh positif dan signifikan terhadap loyalitas pelanggan.

\section{KESIMPULAN DAN SARAN}

\section{Kesimpulan}

Berdasarkan hasil analisis dan pembahasan yang dilakukan mengenai pengaruh variabel kepuasan (X1) dan kepercayaan (X2) terhadap loyalitas pelanggan menggunakan jasa JNE Kota Palu, maka dapat ditarik kesimpulan:

1. Kepuasan dan kepercayaan berpengaruh signifikan secara simultan terhadap loyalitas pelanggan JNE Kota Palu

2. Kepuasan pelanggan berpengaruh signifikan secara parsial terhadap loyalitas pelanggan JNE Kota Palu

3. Kepercayaan berpengaruh signifikan secara parsial terhadap loyalitas pelanggan JNE Kota Palu Saran

Berdasarkan hasil pembahasan, kesimpulan, serta wawancara langsung dengan pelanggan dan pengalaman yang peneliti dapatkan selama proses penelitian ini, maka peneliti memberikan saran sebagai berikut:

1. Pihak JNE Kota Palu Palu hendaknya selalu merawat ruangan agar selalu terlihat bersih dan rapih dan memperluas ruang tunggu juga memperbanyak kursi bagi pelanggan agar tidak ada lagi pelanggan yang berdiri saat mengantri sehingga pelanggan merasa nyaman ketika berada di ruang tunggu.

2. Pihak JNE Kota Palu lebih meyakinkan lagi pelanggannya bahwa kepercayaan akan barang yang dikirim sampai pada tempat tujuan dengan cara memberikan jaminan apabila barang yang dikirim tidak sampai pada tempat tujuan maka pihak JNE Kota Palu akan mengganti barang tersebut dengan barang yang sama dan bersedia untuk mengirim kembali barang tersebut dengan segera tanpa pungutan biaya.

3. Pihak JNE Kota Palu hendaknya mempertahankan hubungan yang baik dengan pelanggannya, sehingga pelanggan merasa bangga menggunakan jasa JNE Kota Palu dan tidak akan berpaling ke perusahaan pesaing.

\section{REFERENSI}

Foster, Bob. 2008. Manajemen Ritel. Bandung: CV Alfabeta. 
Kennedy 2002, Pediatric Operative Dentistryy. Jakarta: EGC

Kotler, Philip and Keller, Kevin Lane. 2013. Marketing Manajement. $12^{\text {th }}$ Edition. London: Pearson Education

Lipiyoadi 2001. Manajemen Pemasaran Jasa Teori dan Praktek, Jakarta: Salemba empat.

Mowen, John C dan Minor, Michael. 2002.Perilaku Konsumen. Jilid 1. Jakarta: PT Penerbit Erlangga. Sugiyono. 2013. Metode Penelitian Bisnis Kuantitatif, Kualitatif, dan R\&D. Bandung: Alfabeta.

Sugiyono. 2016. Metode Penelitian Pendidikan Kuantitatif, Kualitatif, dan R\&D. Bandung: Alfabeta. Eni Hairani dan Marijati sagen (2014) pengaruh kepuasan dan kepercayaan terhadap loyalitas pelanggan LPSB

Wulandari, Kusuma Negara dan Kusuma Dewi (2016) Pengaruh kepuasan, kepercayaan dan harga terhadap loyalitas wisatawan pengguna Booking.com 